\title{
Micronutrient Supplementation does not Change Complement System Response to Heavy Training
}

\section{(๑) (1) $\circledast$}

\author{
Authors \\ José Augusto Rodrigues Santos ${ }^{1}$, Rodrigo Zacca ${ }^{1}$, Ricardo J. Fernandes ${ }^{1,2}$
}

\author{
Affiliations \\ 1 University of Porto, Faculty of Sport, Cifi2d, Porto, \\ Portugal \\ 2 University of Porto, Labiomep, Porto, Portugal
}

\section{Key words}

complement system proteins, $\mathrm{C} 3, \mathrm{C} 4, \mathrm{CH} 100$, vitamins, minerals

$\begin{array}{ll}\text { received } & 10.01 .2017 \\ \text { revised } & 06.04 .2017 \\ \text { accepted } & 04.05 .2017\end{array}$

\section{Bibliography}

DOI https://doi.org/10.1055/s-0043-111403

Sports Medicine International Open 2017; 1: E113-E118

(c) Georg Thieme Verlag KG Stuttgart · New York

ISSN 2367-1890

\section{Correspondence}

Prof. Ricardo J. Fernandes, PhD

University of Porto, Faculty of Sport

CIFI2D

Rua Dr. Plácido Costa, 91

4200, Porto

Portugal

Tel.: + 351/225/074 763, Fax: + 351/225/500 687

ricfer@fade.up.pt

\begin{abstract}
We aimed to examine the micronutrient supplementation effect on complement system activity after heavy training. 24 male firefighters were randomly divided into supplemented and placebo groups, and tested for immunology-related parameters using venous blood samples in the fasting state preand post- 5 weeks of nutritional supplementation. C3 and C4 complement components were determined in a nephelometer from immune complexes formed through specific human antisera and total haemolytic complement activity $(\mathrm{CH} 100)$ was determined by enzyme immunoassay. Differences between pre- and post-supplementation were observed only for $\mathrm{CH} 100$ on placebo group ( $\mathrm{p}=0.004$; mean diff $-26.92 ; 95 \% \mathrm{Cl}-43.58$ to -10.25 ) and no interaction, treatment or time effects were observed for $\mathrm{C} 3$ and $\mathrm{C} 4$. Although interaction accounted for $8.8 \%$ of the total variance in $\mathrm{CH} 100$ (with time effect pre- vs post-accounting for $19.5 \%$ of the total variance), the treatment effect (supplemented vs placebo) was not significant. The absence of effects on the complement system response to supplementation during heavy training could be justified by the fact that: (i) nutritional supplements do not improve humoral innate immunity in well-fed subjects; (ii) selected supplements unlikely improve the innate immune system in situations of adequate nutritional status; and/or (iii) selected doses of supplementation were not sufficient to elicit immune changes.
\end{abstract}

\section{Introduction}

The complement system is an innate immunity key component consisting of proteolytic cascade paths activated by pathogenic microorganisms, immune complexes and auto activation of structurally unstable $\mathrm{C} 3$. Corresponding to the lectin classical and alternative pathways, they lead to formation of a lytic membrane attack complex [23]. Complement plays an important role in inflammation, foreign materials opsonisation, phagocytosis facilitation and direct cytotoxic reactions, working as an antibody-dependent effecter to eliminate pathogens [43]. It regulates several adaptive immune responses and is conditioned by sleep and circadian rhythms, environmental temperature and humidity, ethnicity, physical activity levels, disease, specific nutritional status and ano- rexia nervosa [23, 28, 34]. C3 and C4 complement components are not sensitive to acute psychological stress [35], but although depressive disorders do not affect C3, they might increase $C 4$ serum levels [3].

It has been suggested that exigent physical conditioning elicit changes in the peripheral blood cellular and humoral components of the immune system [7]. This change is related to inflammatory and oxidative stress markers [20] with prolonged exercise and heavy training loads associated with depressed immune function [14]. In fact, well-trained individuals have lower C3 and C4 resting levels [27] and are prone to upper respiratory diseases [13]. Furthermore, nutritional status can directly affect well-trained subjects' immune response to heavy training, because high carbohy- 
drate intake during prolonged exercise limits exercise-induced immune depression [14] and inadequate nutrition negatively influences immunecompetence after heavy exertion [15]. In addition, cellular immunity responds better than humoral immunity to nutritional supplementation, as glutamine supplementation improves: (i) cellular (but not humoral) immunity functions in severely depressed immune system subjects and (ii) cellular immunity (like CD4/CD8 ratio), although IgG, IgM, C3 and C4 plasma concentrations did not change in severe burn patients [29].

Dietary protein and specific micronutrients deficiencies have been associated with immune dysfunction, but benefits regarding high doses of anti-oxidant intake are not sufficiently studied. This is very relevant once antioxidant vitamins and trace elements modulate immune cell function through regulation of redox-sensitive transcription factors [44], although this supplement effect on immune humoral function is not well investigated. Since the complement system is a central mediator of inflammation [43], its improvement might elicit some immune surveillance against exercise-induced inflammatory focus. We aimed to verify if supplementation with antioxidant vitamins, minerals and trace elements can alter immune humoral function and total complement activity after a period of heavy physical exertion. It was hypothesised that supplementation induces complement system benefits post-heavy physical training.

\section{Material and Methods}

\section{Sample}

24 male firefighters volunteered to participate and were randomly divided into supplemented and placebo groups (concealed allocation was implemented). The inclusion criteria were that subjects were professional firefighters; healthy (assessed through medical tests); with no muscular, bone or articular pathologies and visual or hearing deficits; and with a positive classification in physical conditioning tests. Subjects with any incapacitating physical or organic pathology were excluded. There were no differences between groups regarding age, anthropometrical and physical conditioning characteristics ( $\triangleright$ Table 1 ), and no dropouts occurred during the study. Experimental procedures were conducted in accordance with Helsinki Declaration and ethical principles for medical research involving human subjects [16].

\section{Testing protocol}

The current study was randomized, double-blinded and placebocontrolled with supplemented and placebo groups receiving, over 35 consecutive days, a proprietary supplement (Ever-Fit Plus, Prisfar ${ }^{R}$ with $15 \mathrm{mg}$ of beta-carotene, $200 \mathrm{mg}$ of vitamin C, $136 \mathrm{mg}$ of vitamin $\mathrm{E}, 200 \mu \mathrm{g}$ of selenium, $15 \mathrm{mg}$ of zinc and $100 \mathrm{mg}$ of magnesium) and a placebo powder (maltodextrin with artificial flavour and colour), respectively. The training period included 5 microcycles of 5 training units (including 30 min of military drills plus 90 min of technical skills with and without fire protective clothing) and 2 resting days. This and the contents of the weekly physical conditioning program are displayed in $\triangleright$ Fig. 1. Participants avoided physical exertion over the weekends during the study period. Anthropometrical evaluation included stature; body mass; tricipi-
- Table 1 Means plus SD values of age, anthropometrical and physical conditioning characteristics of the participants.

\begin{tabular}{|c|c|c|}
\hline Variables & $\begin{array}{l}\text { Supplemented } \\
\text { group }(n=12)\end{array}$ & $\begin{array}{l}\text { Placebo group } \\
\qquad(n=12)\end{array}$ \\
\hline Age (years) & $22.1 \pm 1.9$ & $23.9 \pm 0.3$ \\
\hline Height (cm) & $174.5 \pm 3.8$ & $174.3 \pm 3.5$ \\
\hline Body mass $(\mathrm{kg})$ & $68.9 \pm 7.4$ & $69.3 \pm 12.3$ \\
\hline Fat mass ( $\%$ body mass) & $9.6 \pm 2.0$ & $10.2 \pm 2.0$ \\
\hline $\begin{array}{l}\text { Bench press with } 50 \mathrm{~kg} \\
\text { (reps) }\end{array}$ & $12.0 \pm 7.1$ & $13.7 \pm 5.7$ \\
\hline Chin-ups (reps) & $15.8 \pm 0.7$ & $15.7 \pm 2.1$ \\
\hline Sprint 50 m (s) & $7.00 \pm 0.0$ & $6.97 \pm 0.05$ \\
\hline Cooper test (m) & $3007 \pm 127$ & $3120 \pm 106$ \\
\hline $\begin{array}{l}\text { Relative peak power } \\
\text { output (watt } / \mathrm{kg})^{*}\end{array}$ & $10.5 \pm 0.5$ & $10.8 \pm 0.1$ \\
\hline $\begin{array}{l}\text { Relative mean power } \\
\text { output (watt } / \mathrm{kg})^{*}\end{array}$ & $7.8 \pm 0.5$ & $8.1 \pm 0.3$ \\
\hline $\begin{array}{l}\text { Relative minimum power } \\
\text { output (watt } / \mathrm{kg})^{*}\end{array}$ & $5.7 \pm 0.8$ & $5.8 \pm 0.6$ \\
\hline Fatigue index (\%) ${ }^{*}$ & $45.9 \pm 6.4$ & $45.2 \pm 6.8$ \\
\hline Squat jump (cm) & $37.3 \pm 5.7$ & $37.8 \pm 3.5$ \\
\hline $\begin{array}{l}\text { Countermovement jump } \\
(\mathrm{cm})\end{array}$ & $38.3 \pm 6.2$ & $39.4 \pm 5.8$ \\
\hline
\end{tabular}

tal, bicipital, sub-scapular and supra-iliac skinfold thickness; and fat mass [39].

All participants received the same physical conditioning and professional skills program during 3 months prior to experimentation, and presented a remarkable similarity in physical fitness in-between groups at the beginning of the study ( $\vee$ Table 1 ). Dietary intake was assessed on 2 weekdays and one weekend day record (one week before the intervention) using a photo album with 134 images containing average raw/cooked food portions. Mean daily food intake was converted to nutrients using Food Processor Plus [1] and no differences between groups regarding pre-supplementation values were observed ( $\triangleright$ Table 2 ). As groups had similar nutritional intake before intervention and firefighters had the same meals during the intervention, they were not tested again for these variables.

Venous blood was drawn from the antecubital vein in a fasting state after 2 resting days in pre- ( 3 months after the start of training activities) and post- 5 weeks of supplementation. Complement components concentration in serum was determined using specific antisera to human C3 and C4 (Codes OSAP and OSAO), with the immune complexes formed measured in a nephelometer (Dade Behring Marburg GmbH, Newark, USA). C3 and C4 were calculated by comparison with known concentration standards. Total haemolytic complement activity ( $\mathrm{CH} 100)$ was determined in human serum by enzyme immunoassay in conjunction with the DiaSorin CAE Kit (Stillwater, Minnesota 55082-0285, USA). Activation level was expressed in complement activation by enzyme immunoassay units. In an attempt to avoid data analysis bias due to analytical variability, all blood samples were analysed in a single laboratory following the same analytical procedures. Main reference values in the literature are $86-184$ and $90-180 \mathrm{mg} / \mathrm{dl}$ for $\mathrm{C} 3,20-58$ and $10-40 \mathrm{mg} / \mathrm{dl}$ for $\mathrm{C} 4$, and $63-145 \mathrm{U} / \mathrm{ml}$ for $\mathrm{CH} 100[8,19]$. 


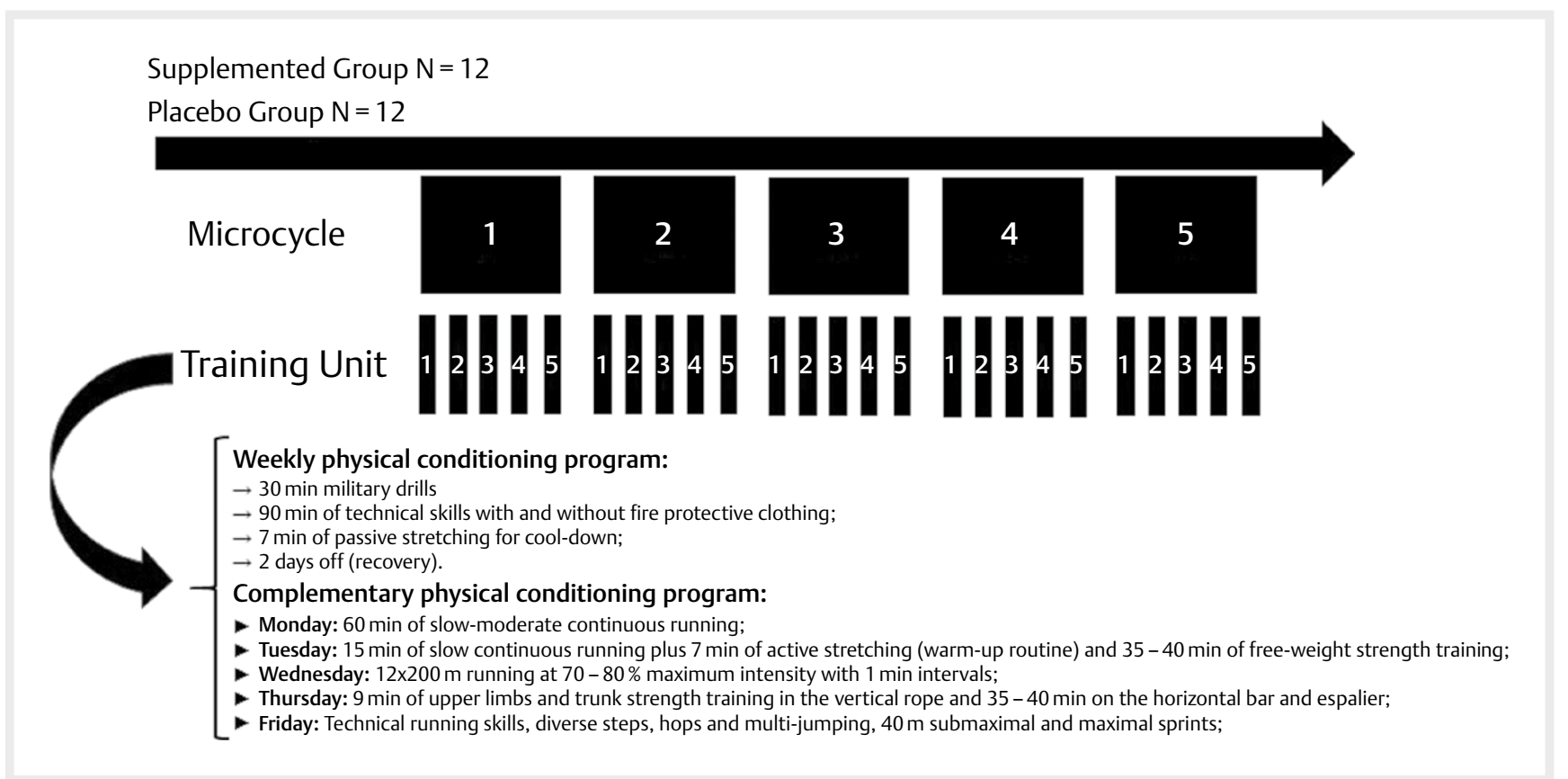

Fig. 1 Physical conditioning program

- Table 2 Means plus SD values regarding nutritional intake before supplementation.

\begin{tabular}{|l|c|c|}
\hline Indicators & $\begin{array}{c}\text { Supplemented } \\
\text { group }(\mathbf{n = 1 2})\end{array}$ & $\begin{array}{c}\text { Placebo group } \\
\mathbf{( n = 1 2 )}\end{array}$ \\
\hline Energy intake $(\mathrm{kcal})$ & $3050 \pm 600$ & $2985 \pm 580$ \\
\hline Carbohydrate $(\%)$ & $51.2 \pm 5.8$ & $50.8 \pm 3.1$ \\
\hline Protein $(\%)$ & $18.4 \pm 2.5$ & $19.2 \pm 2.1$ \\
\hline Fat $(\%)$ & $30.2 \pm 3.3$ & $30.8 \pm 2.8$ \\
\hline Vitamin C $(\mathrm{mg})$ & $147.2 \pm 58.2$ & $152.8 \pm 47.3$ \\
\hline Vitamin $\mathrm{E}(\mathrm{mg})$ & $7.9 \pm 2.3$ & $8.3 \pm 2.8$ \\
\hline Beta-carotene $(\mu \mathrm{g})$ & $165.1 \pm 4.3$ & $158.3 \pm 7.2$ \\
\hline Magnesium $(\mathrm{mg})$ & $431.4 \pm 76.8$ & $411.9 \pm 82.5$ \\
\hline Selenium $(\mu \mathrm{g})$ & $163.3 \pm 22.7$ & $161.9 \pm 54.2$ \\
\hline Zinc $(\mathrm{mg})$ & $16.9 \pm 5.7$ & $17.1 \pm 4.2$ \\
\hline
\end{tabular}

\section{Statistical analysis}

A sample size of 24 subjects was deemed adequate (software $\mathrm{G}^{*}$ Power 3.1.9.2 ${ }^{\odot}$ Heinrich-Heine-Universität Düsseldorf, Germany), assuming $85 \%$ of statistical power and $0.05 \alpha$ error probability. Data were first tested for distribution normality and variance homogeneity. A paired measures t-test was used to compare C3, $\mathrm{C} 4$ and $\mathrm{CH} 100$ values on pre- and post-supplementation conditions for each group. Then, the effects of treatment (supplemented vs placebo) and time (pre- vs post-supplementation) were assessed for each variable using a 2-way ANOVA. When a significant effect was found, the Bonferroni post hoc procedure was performed to localize the difference. Statistical Package for Social Sciences 19.0 was used, with results presented as mean plus standard deviation and statistical significance set at $p<0.05$.

\section{Results}

Regarding micronutrient supplementation (concurrent with heavy physical training), differences for pre- and post-test were observed only for $\mathrm{CH} 100$ in the placebo group ( $\mathrm{p}=0.004$; mean diff -26.92 ; $95 \% \mathrm{Cl}-43.58$ to -10.25 ; cf. $>$ Fig. 2).

ANOVA showed no interaction, treatment or time effect for $\mathrm{C3}$ and C4 ( $\triangleright$ Table 3). Although interaction accounted for $8.8 \%$ of the total variance in $\mathrm{CH} 100(\mathrm{~F}(1,44)=4.249, \mathrm{p}=0.045$, partial $\eta^{2}=0.088$; observed power $\left.=0.522\right)$, with time effect accounting for $19.5 \%$ of the total variance in $\mathrm{CH} 100(\mathrm{~F}(1,44)=10.662$, $p=0.0021$, partial $\eta^{2}=0.195$; observed power 0.891$)$, the treatment effect was not significant $(F(1,44)=0.144, p=0.670$, partial $\eta^{2}=0.04$; observed power $=0.522$ ).

\section{Discussion}

Literature relating to physical training, nutrition and immune humoral system is very scarce, with the current study giving new insights into the influence of several nutrients in humoral immune response in very exhaustive training. The hard physical loads that typical elite athletes (and firefighters) experience induce necrotic material proliferation that can be cleared by complement system activation [23]. This allows opsonisation of damaged tissue prior to its ingestion by phagocytic leukocytes $[38,43]$. Complement pathway activation seems to be independent of exercise type, since aerobic and anaerobic exercises induce similar changes ( $C 3$ and C4 serum levels decrease after both a $30 \mathrm{~s}$ anaerobic test and $30 \mathrm{~min}$ treadmill running $[14,18])$. However, some data are contradictory, because $\mathrm{C} 3$ and $\mathrm{C} 4$ rose after maximal cycling [10] but no alterations were detected immediately after long-lasting exercise [37]. In addition, C3 and C4 values rose during and immediately after $2.5 \mathrm{~h}$ of running (with $\mathrm{C} 4$ continuing to rise some hours after the 

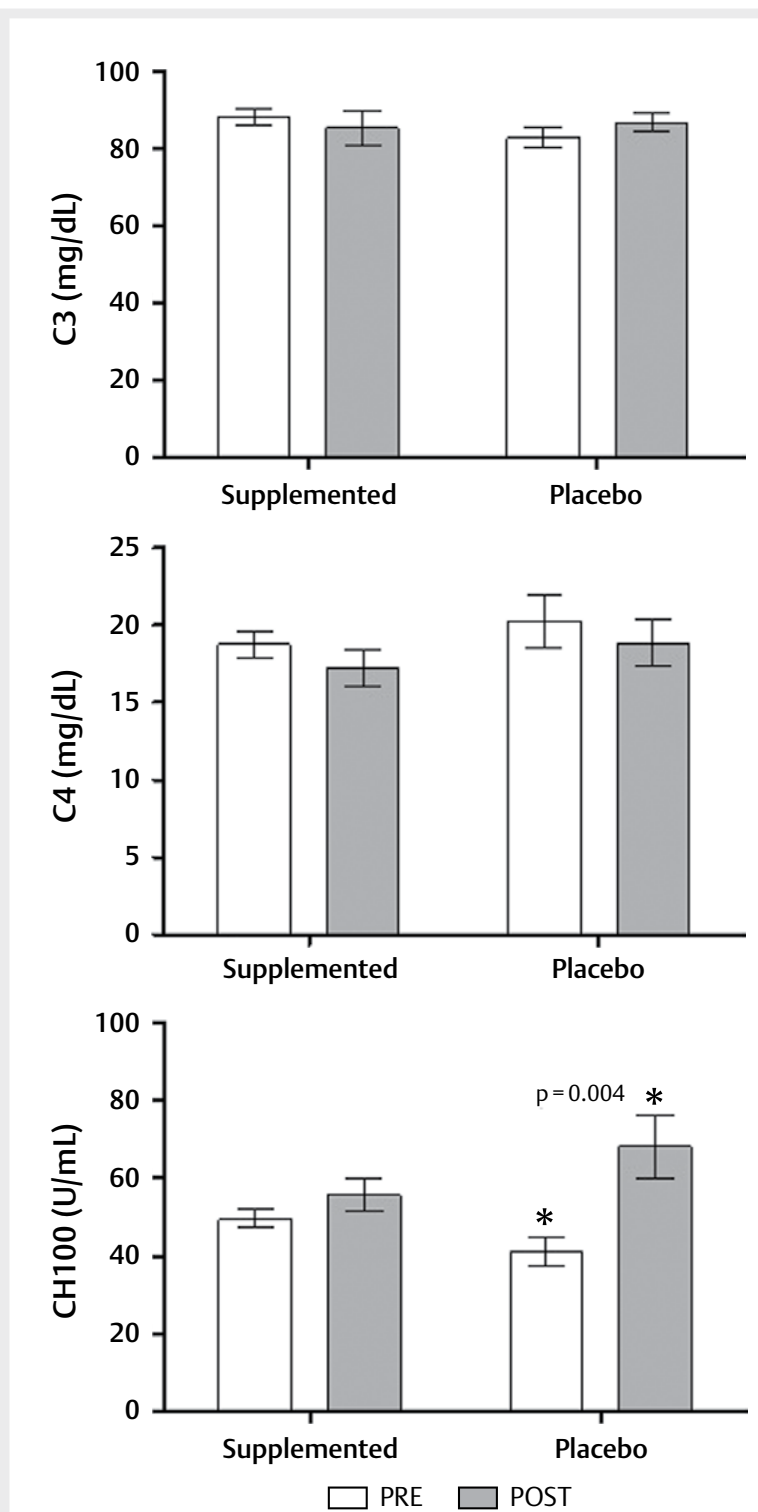

${ }^{*} p<0.004$ Difference between pre- and post-supplementation in the placebo group (mean diff - 26.92; $95 \% \mathrm{Cl}-43.58$ to $-10.25 \mathrm{U} / \mathrm{mL}$ )

Fig. 2 Micronutrient supplementation in both groups

end of the exercise) $[9,43]$, but serum complement decreased after $1-2 \mathrm{~h}$ of recovery in some individuals [26].

C3 and C4 serum concentrations rapidly return to pre-exercise levels after short-term maximal exercise [10,27], but stay slightly lower after an ultramarathon [37], evidencing an exercise moderelated behaviour. These variables are also exercise time-dependent, as long-lasting physical activities induce lower basal C3 levels compared to intermittent exercise, and intermittent sports lead to higher $\mathrm{C} 4$ values than running [3]. Serum opsonic activity and C3 and $C 4$ concentrations did not change immediately after a $100 \mathrm{~km}$ ultramarathon, but recovery can increase their activation towards the muscle debris and other altered molecules' phagocytosis [32]. Heavy exertion elicits strong complement activation, returning quickly to basal levels when exercising at moderate intensity [33]. It was observed that runners had lower basal C3 and haemolytic activity values than non-exercising controls $[14,40]$, with literature differences justified by diverse subjects' physical condition or methodological discrepancies.

In general, exhaustive physical loads induce an acute increase of several complement system components $[4,7,43]$, with systematic heavy physical training depressing their basal values $[14,44]$. This was observed in the current study's $\mathrm{C} 3, \mathrm{C} 4$ and $\mathrm{CH} 100$ data, evidencing a chronic adaptation to high-intensity training loads. Our subjects' average basal serum C3 levels were close to the lowest reference values $[8,19]$ and similar to those found in professional cyclists [36]. The current study's serum C4 levels were lower than some clinical references [19] but within the normal range $[8,36]$. Although not observed in our experiment (cf. > Fig. 2), basal C3 and C4 levels tend to be lower in well-trained subjects $[27,44]$. However, differences between sports should be considered, because no modification of $\mathrm{C} 3$ and $\mathrm{C} 4$ serum levels was observed during a volleyball season [6] despite decreased basal C3 values through aerobic cardiovascular training $[27,30]$.

In the current study, total complement activity (CH100) at presupplementation was lower than laboratory references. This provides insight into the integrity level of the entire classical complement pathway, which is usually elevated in inflammation and infection situations, and decreases with fasting and malnutrition [24]. Although haemolytic activity decreases after short-term aerobic exercise [40], analysis of $\mathrm{CH} 100$ alterations induced by heavy physical training is required. From the current data, we speculate that low basal $\mathrm{CH} 100$ values, in the absence of any known disease or nutritional deficiency, evidence haemolytic activity attenuation subsequent to systematic training. Moreover, $\mathrm{CH} 100$ increased in the placebo group, but no differences between groups were observed both at pre- and post-intervention. However, an increasing tendency after the intervention period was seen for this variable in both groups, suggesting that physical training continuity accentuated haemolytic activity independently of the supplementation.

Complement system enhancement through nutritional interventions is not new, with reduced nutritional intake promoting a decrease in serum C3 and C4 levels $[15,20]$, whereas diets inducing elevated serum low-density lipoprotein cholesterol increased C3 [21]. It is also known that vitamin D deficits are inversely related to C3 serum concentration [31], whereas exercise-induced dehydration increases C3 and C4 serum levels [5]. Dehydration was not taken into consideration in the current study because blood samples were drawn after a $48 \mathrm{~h}$ post-exercise recovery period.

It is accepted that complement system response can be improved by supplementation (at least in situations of nutritional deficits), with cyanocobalamin treatment improving the immune status of vitamin-B12-deficient patients by increasing C3 and C4 levels [11]. However, in well-fed subjects, nutritional supplementation effects are equivocal, because ingestion of mangosteen, multivitamins and essential minerals increased $C 3$ and $C 4$ serum concentration [42] but arginine supplementation did not modify their values [25]. It is also known that histidine-rich glycoprotein binds strongly to several complement proteins, contributing to the maintenance of normal immune function, inhibiting the formation of 
- Table 3 Values (mean \pm SD and $95 \% \mathrm{Cl}$ ) of $\mathrm{C} 3, \mathrm{C} 4$ and $\mathrm{CH} 100$ before and after the training period for supplemented and placebo group.

\begin{tabular}{|c|c|c|c|c|c|c|c|c|}
\hline & \multicolumn{4}{|c|}{ Pre } & \multicolumn{4}{|c|}{ Post } \\
\hline & Supplemented & $95 \% \mathrm{Cl}$ & Placebo & $95 \% \mathrm{Cl}$ & Supplemented & $95 \% \mathrm{Cl}$ & Placebo & $95 \% \mathrm{Cl}$ \\
\hline $\mathrm{C} 3(\mathrm{mg} / \mathrm{dL})$ & $88.2 \pm 7.3$ & 82.1 to 94.2 & $82.9 \pm 9.0$ & 76.8 to 89.0 & $85.4 \pm 15.0$ & 79.3 to 91.5 & $86.8 \pm 8.8$ & 80.7 to 92.9 \\
\hline C4 (mg/dL) & $18.8 \pm 3.1$ & 16.1 to 21.4 & $20.3 \pm 5.7$ & 17.5 to 22.9 & $17.3 \pm 4.1$ & 14.5 to 19.9 & $18.8 \pm 5.2$ & 16.1 to 21.5 \\
\hline $\mathrm{CH} 100(\mathrm{U} / \mathrm{mL})$ & $49.6 \pm 8.1$ & 39.4 to 59.8 & $41.3 \pm 12.8$ & 31.1 to 51.5 & $55.7 \pm 14.3$ & 45.5 to 65.8 & $68.3 \pm 28.1$ & 58.1 to 78.4 \\
\hline
\end{tabular}

insoluble immune complexes (enhancing complement activation) and promoting the faster clearance of necrotic materials [23]. Furthermore, supplementation with a substance isolated from Greenland shark liver increased C1q, C3 and C4 serum levels, improving innate immunity [17].

In the current study, vitamins $\mathrm{C}$ and $\mathrm{E}, \beta$-carotene, selenium, zinc and magnesium did not enhance $\mathrm{C} 3, \mathrm{C} 4$ and $\mathrm{CH} 100$, meaning that humoral immunity responds differently than cellular immunity to supplementation even in situations of great immune stress. Similarly, cellular immunity in severely burned patients was enhanced by glutamine supplementation, whereas humoral immunity did not change [1]. Some reasons might justify the current study data: (i) in well-fed subjects, nutritional supplements do not improve humoral innate immunity; (ii) the selected supplements unlikely improve innate immune system in situations of adequate nutritional status; and/or (iii) the selected micronutrient doses were not sufficient to elicit immune changes.

No differences between groups were observed both at pre- and post-intervention, except for $\mathrm{CH} 100$ that increased in the placebo group. Although time effect accounted for $19.5 \%$ of its total variance, treatment effect was not significant, suggesting an accentuated haemolytic activity with physical training, independent of supplementation. Although it was not possible to verify the same behaviour for all studied variables, the current study's low basal $\mathrm{CH} 100$ values can be the outcome of systematic heavy physical training loads that professional firefighters are accustomed to (worldwide they are typically engaged in this type of heavy physical conditioning). Therefore, these low values are not related to any nutritional inadequacy, because they did not change after micronutrient supplementation (neither did body or fat mass values). Therefore, albeit some studies point out complement system potentiation after supplementation, data should be carefully analysed, because even in situations of increased susceptibility to various infections, micronutrient supplementation can enhance immune response without complement system changes. In type 2 diabetes mellitus patients, vitamins D, E, B1, B2, B6 and C, folic acid, calcium, iron, zinc and selenium supplementation improved immune response to common infections without altering basal C3 and C4 values [17]. The current study participants showed an adequate intake (within RDI) of many micronutrients that are crucial for several components of innate immunity [22], partially justifying the observed ineffectiveness of supplementation.

Lastly, it is important to highlight that different supplementation types probably induce diversified results, necessitating future studies that apply different methodologies. In fact, intensive systematic running induced a C3 decrease delay, restored after administration of ectisten containing tincture of leuzea and leveton [2], and phytoecdysteroids seem to accelerate recovery of immune system affected by exhausting physical work [41]. Nevertheless, large doses of vitamin $\mathrm{C}$ did not change $\mathrm{C} 3, \mathrm{C} 4$ and $\mathrm{CH} 100$ in actively immunized animals [12]. Therefore, the stability of low C3, $\mathrm{C} 4$ and $\mathrm{CH} 100$ levels in our subjects, even after heavy physical training with everyday supplementation, can be explained by the attenuation of the inflammatory response to the physical loads, evidencing a good training adaptation.

We do not consider relevant the differences in $\mathrm{CH} 100$ between groups after supplementation due to the low values obtained. In fact, the higher value obtained in the placebo group was close to the inferior limit, evidencing that this indicator was depressed in both groups in the beginning of the intervention and that supplementation did not alter the situation. We might conclude that 5 weeks of multivitamin and multi-mineral supplementation during heavy training in well-trained and well-fed individuals did not elicit any relevant changes in serum concentration of humoral immunity biomarkers. Future research should further investigate the underlying mechanisms and test the immunity responses to this kind of supplementation in subjects who are not so heavily trained.

\section{Acknowledgements}

To the Immunology Service of St John Hospital (Porto, Portugal) where the laboratory procedures took place.

\section{Conflict of Interest}

The authors declare that they have no conflict of interest.

\section{References}

[1] Amaral T, Nogueira C, Paiva I, Lopes C, Cabral S, Fernandes P, Barros V, Silva T, Calhau C, Cardoso R, Almeida M. Pesos e porções de alimentos. Rev Port Nutr 1993; 5: 13-23

[2] Azizov AP, Seifulla RD, Chubarova AV. Effects of leuzea tincture and leveton on humoral immunity of athletes. Eksp Klin Farmakol 1997; 60: $47-48$

[3] Berk M, Wadee AA, Kuschke RH, O’Neill-Kerr A. Acute phase proteins in major depression. J Psychosom Res 1997; 43: 529-534

[4] Castell LM, Poortmans JR, Leclercq R, Brasseur M, Duchateau J, Newsholme EA. Some aspects of the acute phase response after a marathon race, and the effects of glutamine supplementation. Eur J Appl Physiol 1997; 75: 47-53

[5] Chishaki T, Umeda T, Takahashi I, Matsuzaka M, Iwane K, Matsumoto H, Ishibashi G, Ueno Y, Kashiwa N, Nakaji S. Effects of dehydration on immune functions after a judo practice session. Luminescence 2013; 28: $114-120$

[6] Córdova A, Sureda A, Tur JA, Pons A. Immune response to exercise in elite sportsmen during the competitive season. J Physiol Biochem 2010; 66: 1-6 
[7] Cosgrove C, Galloway SD, Neal C, Hunter AM, McFarlin BK, Spielmann $\mathrm{G}$, Simpson RJ. The impact of 6-month training preparation for an Ironman triathlon on the proportions of naïve, memory and senescent T cells in resting blood. Eur J Appl Physiol 2012; 112: 2989-2998

[8] Dati F, Schumann G, Thomas L, Aguzzi F, Baudner S, Bienvenu J, Blaabjerg O, Blirup-Jensen S, Carlstrom A, Petersen PH, Johnson AM, Milford-Ward A, Ritchie RF, Svendsen PJ, Whicher J. Consensus of a group of professional societies and diagnostic companies on guidelines for interim reference ranges for 14 proteins in serum based on the standardization against the IFCC/BCR/CAP Reference Material (CRM 470). International federation of clinical chemistry. community bureau of reference of the commission of the european communities. college of american pathologists. Eur J Clin Chem Clin Biochem 1996; 34: $517-520$

[9] Dufaux B, Order U. Complement activation after prolonged exercise. Clin Chim Acta 1989; 179: 45-49

[10] Dufaux B, Order U, Liesen H. Effect of a short maximal physical exercise on coagulation, fibrinolysis, and complement system. Int J Sports Med 1991; 12: S38-S42

[11] Erkurt MA, Aydogdu I, Dikilitas M, Kuku I, Kaya E, Bayraktar N, Ozhan O, Ozkan I, Sonmez A. Effects of cyanocobalamin on immunity in patients with pernicious anemia. Med Princ Pract 2008; 17: 131-135

[12] Feigen GA, Smith BH, Dix CE, Flynn C], Peterson NS, Rosenberg LT, Pavlovic S, Leibovitz B. Enhancement of antibody production and protection against systemic anaphylaxis by large doses of vitamin C. Res Commun Chem Pathol Pharmacol 1982; 38: 313-333

[13] Galazka-Franta A, Jura-Szoltys E, Smollka W, Gawlik R. Upper respiratory tract diseases in athletes in different sports disciplines. J Hum Kinet 2016; 53: 99-106

[14] Gleeson M. Can nutrition limit exercise-induced immunodepression? Nutr Rev 2006; 64: 119-131

[15] Gleeson M, Nieman DC, Pedersen BK. Exercise, nutrition and immune function. J Sports Sci 2004; 22: 115-125

[16] Harriss D], Atkinson G. Ethical standards in sport and exercise science research: 2016 update. Int J Sports Med 2015; 36: 1121-1124

[17] Henryk T, Ewa G, Malgorzata B, Przemyslaw L. The effect of alcoxyglycerols, squalene and $\mathrm{n}-3$ fatty acid on some innate immunity parameters in healthy people. Pol Merkur Lekarski 2005; 18: 303-306

[18] Karacabey K, Saygin O, Ozmerdivenli R, Zorba E, Godekmerdan A, Bulut $V$. The effects of exercise on the immune system and stress hormones in sportswomen. Neuro Endocrinol Lett 2005; 26: 361-366

[19] Kratz A, Ferraro M, Sluss PM, Lewandrowski KB. Case records of the Massachusetts General Hospital. Weekly clinicopathological exercises. Laboratory Reference Values. N Engl J Med 2004; 351: 1548-1563

[20] Laskowski R, Ziemann E, Olek RA, Zembron-Lacny A. The effect of three days of judo training sessions on the inflammatory response and oxidative stress markers. J Hum Kinet 2011; 30: 65-73

[21] Lee HS, Park HJ, Nam JH, Kim MH, Kim WY. Immune and nutrition status in elderly Koreans with hyperLDL-cholesterolemia. J Nutr Sci Vitaminol 2006; 52: 407-413

[22] Liu Y, Jing H, Wang J, Zhang R, Zhang Y, Zhang Y, Xu Q, Yu X, Xue C. Micronutrients decrease incidence of common infections in type 2 diabetes outpatients. Asia Pac J Clin Nutr 2011; 20: 375-382

[23] Manderson GA, Martin M, Onnerfjord P, Saxne T, Schmidtchen A, Mollnes TE, Heinegard D, Blom AM. Interactions of histidine-rich glycoprotein with immunoglobulins and proteins of the complement system. Mol Immuno 2009; 46: 3388-3398

[24] Montanari M, Violi V, Muri M, Roncoroni L, Mora G, Ronzoni M. Early decrease in total haemolytic complement activity $(\mathrm{CH} 100)$ after fasting or intestinal bypass in the rat. Eur Surg Res 1986; 18: 36-40

[25] Moriguti JC, Ferriolli E, Donadi EA, Marchini JS. Effects of arginine supplementation on the humoral and innate immune response of older people. Eur J Clin Nutr 2005; 59: 1362-1366
[26] Nieman DC, Nehlsen-Cannarella SL. The effects of endurance exercise on the immune response. In: Astrand PO, Shephard RJ.(eds) Endurance in Sport. Oxford: Blackwell Scientific Publ; 1991: 200-211

[27] Nieman DC, Tan SA, Lee JW, Berk LS. Complement and immunoglobulin levels in athletes and sedentary controls. Int J Sports Med 1989; 10: 124-128

[28] Nova E, Lopez-Vidriero I, Varela P, Toro O, Casas J, Marcos A. Indicators of nutritional status in restricting-type anorexia nervosa patients: A 1-year follow-up study. Clin Nutr 2004; 23: 1353-1359

[29] Peng X, Yan H, You Z, Wang P, Wang S. Glutamine granule-supplemented enteral nutrition maintains immunological function in severely burned patients. Burns 2006; 32: 589-593

[30] Ruiz JR, Ortega FB, Warnberg J, Sjostrom M. Associations of low-grade inflammation with physical activity, fitness and fatness in prepubertal children; the European Youth Heart Study. Nt J Obes 2007; 31: 1545-1551

[31] Sakem B, Nock C, Stanga Z, Medina P, Nydegger UE, Risch M, Risch L. Serum concentration of 25-hydroxyvitamin D and immunoglobulins in an older Swiss cohort: Results of the Senior Labor Study. BMC Med 2013; 11: 1-9

[32] Sato H, Abe T, Kikuchi T, Endo T, Hasegawa H, Suzuki K, Nakaji S, Sugawara K, Ohta $\mathrm{S}$. Changes in the production of reactive oxygen species from neutrophils following a $100-\mathrm{km}$ marathon. Nihon Eiseigaku Zasshi 1996; 51: 612-616

[33] Sato H, Suzuki K, Kakaji S, Sugawara K, Totsuka M, Sato K. Effects of acute endurance exercise and 8 week training on the production of reactive oxygen species from neutrophils in untrained men. Nihon Eiseigaku Zasshi 1998; 53: 431-440

[34] Saygin O, Karacabey K, Ozmerdivenli R, Zorba E, Ilhan F, Bulut V. Effect of chronic exercise on immunoglobulin, complement and leukocyte types in volleyball players and athletes. Neuro Endocrinol Lett 2006; 27: $271-276$

[35] Segal AB, Bruno S, Forte WC. Immune function in acute stress. Allergol Immunopathol 2006; 34: 136-140

[36] Semple SJ, Smith LL, McKune AJ, Hoyos J, Mokgethwa B, San Juan AF, Lucia A, Wadee AA. Serum concentrations of $C$ reactive protein, $\alpha 1$ antitrypsin, and complement (C3, C4, C1 esterase inhibitor) before and during the Vuelta a España. Br J Sports Med 2006; 40: 124-127

[37] Semple SJ, Smith LL, McKune AJ, Neveling N, Wadee A. Alterations in acute-phase reactants (CRP, rheumatoid factor, complement, Factor B, and immune complexes) following an ultramarathon. S Afr J Sports Med 2004; 16: 17-21

[38] Shephard RJ, Shek PN. Acute and chronic over-exertion: do depressed immune responses provide useful markers? Int J Sports Med 1998; 19 : 159-171

[39] Siri WE. Body composition from fluid spaces and density: analysis of methods. In: Brozek J, Henschel A.(eds) Techniques for Measuring Body Composition. Washington DC: National Academy of Sciences, National Research Council; 1961: 223-244

[40] Smith JK, Chi DS, Krish G, Reynolds S, Cambron G. Effect of exercise on complement activity. Ann Allergy 1990; 65: 304-310

[41] Syrov VN, Shakhmurova GA, Khushbaktova ZA. Effects of phytoecdysteroids and bemithyl on functional, metabolic, and immunological parameters of working capacity in experimental animals. Eksp Klin Farmakol 2008; 71: 40-43

[42] Tang YP, Li PG, Kondo M, Ji HP, Kou Y, Ou B. Effect of a mangosteen dietary supplement on human immune function: A randomized, double-blind, placebo-controlled trail. J Med Food 2009; 12: 755-763

[43] Tsukamoto H, Horiuchi T. Clinical aspects of the complement system. Rinsho Byori 2006; 54: 757-762

[44] Wintergerst ES, Maggini S, Horniq DH. Contribution of selected vitamins and trace elements to immune function. Ann Nutr Metab 2007; 51: 301-323 